\title{
EVOLVING LEGAL AND INSTITUTIONAL FRAMEWORKS OF NEOLIBERAL URBAN POLICIES IN TURKEY
}

\author{
Serap KAYASÜ*, Emine YETIŞKUL*
}

Received: 01.06.2014; Final Text: 20.11.2014

Keywords: Neoliberalism; legal and institutional frameworks; urban policy.
* Department of City and Regional Planning, METU, Ankara, TURKEY.

\section{INTRODUCTION}

Geographical perspectives on neoliberalism unraveling the connections between neoliberalisation and urban processes have long been the focus of academic inquiry (Brenner et al., 2009; Brenner and Theodore, 2002; Jessop, 2002; Peck and Tickell, 2002; Peck et al., 2009). A substantial body of literature analyses urban development patterns in Turkey with a particular reference to neoliberalism as well. The focus of these analyses range from an emphasis on restructuring metropolitan areas to bring about functioning land and property markets in the search for a neoliberal modernisation of the city (Lovering and Türkmen, 2011) to a discussion on the changing urban policy framework through analyses of neoliberalism as a political rationality (Karaman, 2013). The judicial and administrative contexts are elaborated (Eraydın, 2012; Türkün, 2011) to explore the ways in which neoliberal policies affect urban development and planning system in Turkey. Large urban transformation projects are considered to be the main mechanisms through which a neoliberal policy scheme targeting incompletely commodified urban areas (Kuyucu and Ünsal, 2010), whereas negative impacts of construction activity by either public (Balaban, 2012) or private sectors on urban spatial processes constitute a significant outcome of neoliberal urban policies.

This study assesses the evolution of legal and institutional frameworks of neoliberal urban policies in Turkey. In this context, changing power dynamics among different actors of policy making are elaborated. A particular emphasis is given to power shifts between the central and local governments. However the overpowering dominance of the central government has persevered in its influence on Turkish neoliberal urban policies.

In this paper the development of neoliberal urban policy in Turkey during the last thirty years is addressed within two periods. The first period begins with economic restructuring policies of the 1980s. This period is signified 
1. The concept of urban transformation is defined as urban focused economic strategy making by Lovering and Evren (2011). They refer to a range of perspectives on the dynamics of what is called 'Urban Regeneration' in Western Europe and North America. It should be emphasised in the context of this paper, however, that the concept of urban transformation does not entail the economic and social aspects of spatial change that is referred by the concept of urban regeneration. by Structural Adjustment Policies and the deregulation of the trade and finance systems under the impact of increased market forces. The second period, the 2000s, involves legal and institutional restructuring mainly inspired by the EU alignment process. The Local Administration Reform Package involving major legal and institutional changes was introduced during this period. The second decade of the 2000s also witnessed wide ranging urban transformation policy promoted by the central government with the motivation for increasing urban rent and property development under the impact of neoliberalism (1). Although both periods involved changes that led local governments to become more powerful actors in urban policy making, urban transformation policy has been increasingly accompanied by strong indications of centralisation of power. Major legal and institutional changes particularly with regard to Mass Housing Authority (TOKI) and the newly established Ministry of Environment and Urbanism have marked the latter period. The structure of the paper as follows. The next section includes a discussion on neoliberalism and governance with a particular focus on contingencies involving the dominance of central government. In the following sections neoliberal periods are scrutinised in order to explore the ways in which changes in legal and institutional frameworks transform the domain of urban policy making in Turkey. Intertwined relations among the roles of actors shaped under the prevailing power dynamics and the formation of urban policies through different phases of neoliberalism constitute the theme of the study. The final section is on the implications of current urban transformation policy.

\section{NEOLIBERAL POLICIES AND GOVERNANCE}

The emergence of neoliberal policies signifies a transformation from state centered economic development approaches to entrepreneurial, competitive and market based economic development. Neoliberal urban policies are characterised by the nexus between investment capital, intercity competition and public entrepreneurialism (Sager, 2011). Neoliberalism reconstitutes relationships between public institutions and key actors of market, reducing the activity of government and encouring non-government agencies and individuals and motivating civil society to take on more activities previously done by government. Since the 1980s the focus of urban policy has shifted away from managing city growth and the negative externalities of accelerated urbanisation towards coping with the consequences of economic and spatial restructuring (Fainstein, 1991; Moulaert and Scott, 1997).

Neoliberal ideology suggests "open, competitive, and unregulated markets, liberated from all forms of state interference, represent the optimal mechanism for economic development" (Brenner and Theodore, 2002, 2). Actual neoliberal policies and practices involve "coercive, disciplinary forms of state intervention in order to impose market rule upon all aspects of social life" (Brenner and Theodore, 2002, 5), whereas neoliberal ideology criticises state intervention. In Harvey's definition of neoliberalism, "state interventions in markets (once created) must be kept to a bare minimum because the state cannot possibly possess enough information to secondguess market signals (prices) and because powerful interest groups will inevitably distort and bias state interventions (particularly in democracies) for their own benefit" (Harvey 2005, 2). 
Peck and Tickell (2002) identify two interrelated phases or processes of neoliberalism: "roll-back" and "roll-out" to clarify the ways in which neoliberal policy has developed. The "roll-back" process involves the retreat from previous governmental control of resources and state regulations including public services. It can also be conceptualised as privatisation involving the delegation of authority to for-profit and nonprofit agencies. This process may involve the dismantling of institutions, disorganising alternate centres of power, deregulating of bureaucratic control (Peck, 2010, 22). The "roll-out" process refers to "the purposeful construction and consolidation of neoliberalised state forms, modes of governance, and regulatory relations" (Peck and Tickell, 2002, 37). This process also involves public-private initiatives and socially interventionist policies. This new form of governance considers state intervention and public spending as being plausible. Roll-out neoliberalism involves an internal logic, brought about by failures of simple deregulation, and a contextual dynamic, brought about by increased reliance on various institutional supports, mechanism and policy adjustments (Peck and Tickell, 2002, 23). Contradictions of neoliberalism has often been pointed out (Peck, 2010; Swyngedouw et al., 2002). In fact, neoliberalism represented a continuous process of construction. Neoliberalisation is not the antithesis of regulation, but rather "a self-contradictory form of an adaptive, mutating and contradictory mode of governance." Uncovering neoliberalism requires "following flows, backflows, and undercurrents across and between these ideational, ideological and institutional movements, over time and between places" (Peck, 2010, xiii).

The new structures of urban governance adopt public institutions to be enterprising, risk-taking, inventive, and profit motivated in their entrepreneurial role (Sager, 2011). New urban governance have also encouraged a proliferation of partnership agencies, semi-public bodies and contracting arrangements, in which government work together with representatives of business, communities, voluntary groups and interest associations (Le Gales, 2002). Neoliberal developments have created the diffuse urban governance landscapes, often referred to as "fragmented" (Healey, 2007). This more diffused, fragmented, and flexible mode of governance is one of the most striking aspects of neoliberal urbanisation (Swyngedouw et al., 2002). The combination of different spatial and administrative scales and the increasing fragmentation of competencies and responsibilities play a key role in urban policy making domain of neoliberalism. This new urban governance reflects a shifting geometry of power (Swyngedouw et al., 2002, 5). It has also contributed to the redefinition of roles played by local governments, reinforcing the tendency towards a more proactive approach that makes local governments act simultaneously as enablers, partners, and clients. Thereby it can be stressed that in an effective form of roll-out neoliberalism power shifts to local governments could be favoured.

Several studies illustrate that the level and degree of institutional reorganisation of urban governance are highly differentiated and contextdependent. Evidence is provided for countries such as Portugal, Ireland, Australia and France regarding contingent forms of governance within which the roles enacted by central governments are emphasised (BredaVázquez et al., 2009; McGuirk, 2000; 2005; Nicholls, 2005). Breda-Vázquez et al. (2009) focus on the relationship between the diversity of partnerships and the processes of institutional changes while stressing the role of governance culture in urban regeneration policies of Portugal. In this 
context the significance of a national framework for urban policies is highlighted. It is considered to be an essential issue for the development of the values and visions that frame solutions to problems and practices for building networks and coalitions. McGuirk (2005) substantiates the claim that neoliberalism is not a unified coherent project, but rather a series of complex and overlapping strategies that produces hybrid and always emergent forms of governance. Upon tracing the history of metropolitan planning for the Sydney region, the state agency is considered to be directive and interventionist (McGuirk, 2005).

In Turkey different institutional reorganisations of urban governance, under the impact of neoliberal policies, have been practiced through the introduction of various legal instruments. The main features of governance reflect the unique and distinctive administrative characteristics. Traditional central government based administrative system has shaped all forms of governance in Turkey. Moreover participation of key actors to policy making processes has not been a strong part of urban administration. Kuyucu and Ünsal (2010) represent the complete lack of models for participation in the relevant laws and institutions while revealing local reactions and resistance to two large urban transformation projects in previously squatter housing areas of İstanbul. The lack of subtle approaches to secure upfront cooperation in these cases is also emphasised by Lovering and Türkmen (2011). In fact, they call Turkey's highly centralised and top-down approach to urban transformation as bulldozer neoliberalism.

In our study it is claimed that power dynamics have often worked in favour of those actors who hold power in the distribution process of urban rent throughout the evolution of Turkish neoliberal urban policy. Although power shifts between the central government and other key actors have shaped various forms of governance at certain times under the impact of neoliberalism, the traditional administrative system has always sustained with overpowering impacts. As a matter of fact, urban development has always been considered to be the basis of capital accumulation processes in Turkey. Redistributive policies have ensured investments through the privatisation of public land and the production built environment (Keskinok, 2006; Şengül, 2009).

The strategies that relied on free market dynamics and competition was successfully implemented up until the 1990s with neoliberalism (Karaman, 2013). The new government of the 2000s also followed to implement various forms of neoliberal governance in the face of EU Accession Process. Many legal and institutional instruments were introduced to fasten the implementation of rolling back policies involving the processes of privatisation and deregulation. However, the structural adjustment policies of two different periods, i.e. Local Reform Packages of the 1980s and 2000s, actually could not be followed by new forms of institution building and progress in governance. It is claimed here that roll-back phases of neoliberalism have been effective in Turkey, whereas roll-out neoliberalism has never actually existed due to the ways in which traditional legal and institutional frameworks have evolved. Owing to the limitations and contradictions of the roll-back neoliberal phases throughout both periods, roll-out neoliberalism could not be induced. All in all the reconstruction of neoliberalised government forms, governance relations and regulatory reforms failed to follow the earlier phases of neoliberalism. This is to say that the attempts to attain successful modes of governance have remained rather frail within the context of neoliberal urban policies in Turkey. 


\section{NEOLIBERAL URBAN POLICIES: 1980- 2000}

The 1980s involved a major restructuring period that led to the reconceptualisation of economic and urban development. Neoliberal policies paved the way for a large scale involvement of market dynamics into the control functions of the central government (Keyder and Öncü, 1993; 1994) in Turkey. The transition to market dynamics, nevertheless, required major changes in legal and institutional frameworks of urban policy making. Implications of neoliberal orientation could be detected in the changing power dynamics between central and local governments. The 1984 Local Government Reform constituted a major step for shifting power, which involved central government's commitment to share authority with municipalities. Main objective of the 1984 Local Government Reform was to enable municipalities to be responsive toward citizens' needs through some degree of decentralisation, which would lessen their dependence on the central government (Heper, 1986). Two major ministries related to public works and planning were merged into one institution. The Ministry of Public Works and Settlement was established in this context, involving the transfer of competencies to municipalities.

Devolving the central government's authority to municipalities was already on the national political agenda in Turkey during the 1970s. The rise of municipal movement that sought greater power represented a trend in local administrative politics of the 1970s (Finkel, 1990). Furthermore the rise of urban concerns, problems and demands as major issues forced municipalities to develop innovative strategies involving solutions in fund raising as well as networks and unions. The 1984 Local Government Reform was carried out in response to the increasing pressure for change. Financial resources of the municipalities were improved and the range of duties and responsibilities was expanded.

Metropolitan Municipality Law no. 3030 was enacted in 1984, initiating a two-tier municipal structure in metropolitan cities. Initially three largest cities in Turkey, i.e.İstanbul, Ankara and Izmir, were promulgated as metropolitan cities (2). Parallel to the extension of municipality boundaries, the domain of metropolitan municipalities also expanded. At the same time the political status and power of the metropolitan mayors have been significantly enhanced (Kalaycıŏlu, 1989). For instance, metropolitan municipalities that have been carrying out the preparation, approval and implementation of master plans have also been approving and auditing the implementation plans of district municipalities. These auditing and stepping in processes have constituted a particular power mechanism that have been exercised to control district municipalities.

Despite new legal and institutional instruments that transfer authority to municipalities particularly in local plan making, certain legislative changes still provided power to central government. To this end, Urban Planning Law no. 3194 that regulates the development of urban built environment passed in 1985. The Urban Planning Law contains significant aspects as it carries forth many bylaws providing a practice within which municipalities could not develop urban local codes and principles. This law covers those certain exceptions that are applied to specified areas. Specified areas include conservation areas (cultural and natural heritage,

2. Total population of three metropolitan municipalities in 1985 became 5.48, 2.24 and 1.49 million. The number of metropolitan municipalities has continuously increased since then reaching up to 8 in 1990 and 16 in 2000 (TSI, 2014) special environmental protection areas, national parks) and project based urban development areas (tourism development areas, mass housing areas, areas in the scope of privatisation). These exceptions actually constitute priviledges of the central government. This implies that all 
planning activities could be controlled directly by the central government whenever 'deemed necessary' (Ersoy, 1992). Moreover, a number of other legal instruments have been put into effect that allocate power to various central government institutions. These instruments leading to overlapping authorities in planning have profound impact on urban development. The Privatisation Administration, Ministry of Culture and Tourism and Mass Housing Administration constitute the examples of central planning institutions that have the authority of designating specified development rights. These development rights contradict with local policies and plans while challenging the existing infrastructure due to increased densities.

Priviledges were defined to assure project based development faster bypassing bureaucratic processes. Partnerships between public and private sectors play crucial roles for the realisation of project based urban development. The Tourism Encouragement Law no. 2634 in 1982, for example, involved private sector in large scale investments and allocated public land plots for tourism development by reducing bureaucratic formalities for investors. Incentives were given to entrepreneurs in tourism zones. The Mass Housing Law no. 2985 passed in 1984 with the aim of providing authorised housing for urban population by establishing an institution affiliated with the central government to finance, plan, implement and control the mass housing development processes. The central government's involvement in urban development accelerated, owing to housing provision through the establishment of partnerships between TOKİ and the private sector.

Prevalent strong central government interventions in urban development augmented under the impact of neoliberal policies through further introduction of legal and institutional instruments. Certain priviledges shifted power to the central government to ease intervention. In this sense the contingent neoliberalisation processes in Turkey co-existed with the centralisation of power by evolving legal and institutional frameworks. The period between 1980 and 2000 signifies the initial roll-back phase of neoliberal urban policies in Turkey. Further legal and institutional frameworks that have been introduced to enable the implementation of roll-back policies involved privatisation and deregulation. Paradoxically the roll-back process involved not only deregulation and devolution, but also new forms of priviledged power for the central government. This is to say that power dynamics changed substantially in favour of the private sector's share of urban rent during this period whereas the central government regulations continued.

\section{NEOLIBERAL URBAN POLICIES: 2000-}

The beginning of 2000s witnessed a major restructuring process since Turkey gained EU candidate status with the decision of Helsinki Summit. Restructuring legal and institutional frameworks in the face of EU accession process modified the contents of urban policy making. Turkey's attempts to embed the institutional and policy environment of the EU was compelling the country to establish a fitting structure of governance (Lagendijk et al., 2009). Three significant laws were issued in the context of a Local Administration Reform Package in 2004. The aim of the reform package was to fasten the devolution of authority to local governments. Three laws were issued to constitute a new mechanism for municipalities, metropolitan municipalities and special provincial administrations. These 
laws carried forth significant changes in the functional, institutional and financial structures of local governments.

Metropolitan municipalities and municipalities were restructured with the Metropolitan Municipality Law no. 5216 in 2004 and Municipality Law no. 5393 in 2005, respectively. The practice within which municipal council decisions would enter into force only after the approval of the administrative authority of the central government is abolished, and municipalities should make and implement their decisions within their authorised bodies. For instance, the abolishment of municipality councils is also a considerable step. Secondly, institutional structure of municipalities become flexible so that they can create their internal organisation through their own decision making processes. They are also regarded as the general authority in the provision of local services. Municipalities can fulfill other services and duties that are not specified in the laws, which supports the full discretion right of local governments. Thirdly, positive improvement take place in the method of budget finalisation process. There is no requirement for the approval of the central governor to finalise the budget. Municipalities institute firms, borrow capital, issue shares and paper assets. By these laws municipalities have also a chance to establish stock corporations within the realm of their authority (Ministry of Interior, 2012). In addition, an independent law on unions also enables municipalities to collaborate in networks. Active participation of civil society actors in decision making processes are also promoted.

The Special Provincial Administration Law no. 5302 in 2005 defines the administrative and financial autonomy, which is set up to meet the local needs of provinces. Provincial Administration Councils are elected bodies. These administrations assume the same responsibilities as municipalities at the provincial scale, and also cooperate with them. It should be noted that the planning competences of special provincial administrations are transferred to the metropolitan municipalities by Law no. 6360 in 2012. Moreover the control of public investments passed to that of central government with the same law, easing the bypass of local governments in decision making processes. Currently 30 metropolitan municipalities are defined under this law (3).

The Local Administration Reform Package intended to strengthen the institutional capacity of local governments by power shifts from the central government. Strategic plans and performance based budget preparation are made compulsory for local governments. Participation of universities, nongovernmental organizations and professional chambers in decision and strategic plan making are introduced. The introduction of strategic plans that are prepared with participatory approach is a significant step. This process generates a perspective for a mode of governance that is contingent to the circumstances in Turkey. New mechanisms and practices that the Local Administration Reform Package entails actually support civil society actors' participation in policy making. The changes introduced by this rollout phase of neoliberalism initially provided a possibility of accomodating a form of governance in Turkey. However, this proved to be a difficult goal to attain due to the strong centralised urban administrative tradition.

3. Population of İstanbul Metropolitan Area is 14.16 million, accounting 20.22 percent of country's total population in 2013. In Ankara and Izmir, populations are 5.05 million and 4.06 million, respectively (TSI, 2014). Currently nearly half of the country's population is living in metropolitan municipalities.
Local governments are still dependent on the central government for a large proportion of their revenues. In addition city councils, designed to encourage citizens' participation in local government, have functioned effectively in only a limited number of cities. Participation principle and collaboration in union networks have not been fully implemented, and 
4. Tourism Encouragement Law no.4957 in 2003; Law no.5398 on Arranging Privatisation Implementations and Amending Several Laws in 2005; Law no. 5403 on Soil Preservation and Land Utilisation in 2005; Law no.5335 on Amending Several Laws and Decree Laws in 2005.

5. The example of the development of 'Levent-Maslak' axis, financial and central business district neighbourhood of İstanbul, is an illustration of how central government can override the Master Plan of the Metropolitan Municipality. The plan aims to preserve the natural forestry and water catchment areas through a spatial strategy that prohibits urban development on the northern part of the city. Main role for the development of the axis is the Ministry of Culture and Tourism who has the authority to undertake projects under the 'Tourism Encouragement Law' (OECD, 2008). Corollorary to this, the central government's interventions carried on with the decisions on the 'Third Bosphorus Bridge', which is currently under construction. Another example is the 'Canal İstanbul Project', with massive land expropriations and displacements, distributing the urban rents and redistributing property gains. Even though these mega projects are promoted by the central government as a political instrument, none of them is included in the Master Plan. The central government's ad hoc direct influence is prominent for the interventions of municipalities in these urban projects. Mega projects come into agenda either through an enactment of certain priviledges for a particular area or through the implicit authority of the central government.

6. Law no.4966 in 2003; Law no.5162 in 2004; 5273 in 2004; Law no. 5273 in 2004; Law no.5609 in 2007; Law no.5582 in 2007; Law no. 5793 in 2008. should be regarded as initial efforts. This reform took place within the context of the European Charter on Local Self-Government, and local governments have become comparatively powerful, participatory and accountable. However, they are still not in complete harmony with the Charter in regard to financial autonomy and the formation of unions (Parlak et al.,2008). The European Commisson's Turkey 2012 Progress Report (EC, 2012) indicates that there had been rather limited progress in the efforts for devolving authority to local governments.

Various elements of neoliberalism under the EU Accession Process in the first decade of the 2000s involved the introduction of alternative legal and institutional frameworks and the reorganisation of traditional institutions. Much speculation took place particulary regarding a transformation from a centralised to a decentralised government structure. The debate on the establishment of Development Agencies at NUTS II levels and the abandonment of top to bottom institutional structures constitutes one of the examples, prevailing power dynamics have not changed dramatically. Even though this roll-out phase of neoliberalism involves regulatory incursions that are suitable for the markets, including the empowerment of nongovernmental organisations. This phase could not lead to effective modes of governance in Turkey. All in all the legal and institutional frameworks under the roll-out phase of neoliberalism in Turkey encompass only attempts for power shifts between central and local governments.

\section{URBAN TRANSFORMATION POLICY}

The redistribution of competences to various central government institutions, causing an overlap between central and local governments, continues to be the core of urban policies during the 2000s in Turkey (4). In 2003, the Tourism Encouragement Law no. 4957, for example, amended the previous law on tourism investments, which widens the authority of the Ministry of Culture and Tourism in planning, public land allocation and certification for tourism zones. The intervention of central power to local planning processes through tourism development areas has not been introduced for the first time. Nevertheless its negative impact on urban development has become more complex. The Privatisation Administration, a department under the supervision of the Prime Ministry, has become another powerful central public institution with the enactment of the Law no. 5398 in 2005. The integrity of urban policies is disregarded, and interventions to the local dynamics are exercised more often especially through priviledges (5).

Another institutional framework embodied by TOKİ has been effective in the formation of urban policy during the 2000s. As a result of the changes in legal and institutional instruments, amending the powers and responsibilites of TOKİ, the institution has further acquired considerable power (6). Preparation of plans, when the ownership of land has been transferred to TOKI; planning and selling the public land for the purpose of urban land development and housing provision are the responsibilities assigned to this institution. With a few re-organisational changes, for example, the responsibilities and authority of former Land Office were transferred to TOKİ as well. Furthermore, the administration is enabled to act as a private enterprise and establish new companies and partnerships with others. Thereby, TOKİ becomes a even more powerful and autonomous institution not only in legal and administrative, but also in financial issues. The central government enables large scale 
7. Neoliberal policies of mid-1980s included a series of amnesties as a government attempt to integrate gecekondu housing areas into authorised housing (Laws no. 2805 in 1983; 2981 in 1984; 3290 in 1986; 3366 in 1987). As a matter of fact, with the amnesty laws Development Improvement Plans were introduced for legitimising gecekondus while prohibiting further squatter construction. These improvement plans resulted in increases in building densities without upgrading the level of public and infrastructure services.

Gecekondu owners had been in the political arena and their patronage relationships enabled them to take active roles for the enactment of amnesties. This was coupled with the pressures of the private sector for opening inner city areas for urban development. Thereby, the gecekondu housing stock became an important source of urban rent and was opened to different models of transformation (Şenyapill, 2004). Transformation took place on the individual parcel basis by limited capital outlay under demolish and rebuild method. This transformation was processed by informal networks (Erder, 1996; Işık and Pınarcıoğlu, 2001). These processes had redistributive effects for particular interest groups (Buğra, 1998).

In the context of urban policy making the implications of reemerging central government's power are twofold. On one hand they serve the interests of private sector through the transfer of certain rights and resources. On the other hand, due to populist politics, they provide amnesties for gecekondus. private sector's entry into the construction sector by either directly financing the sector through TOKİ or establishing partnerships with local governments. Opening up high urban rent potential areas either for the central government or for the private sector, TOKİ is definitely not using its authority to provide affordable housing to low-income segments of urban population, which was the initial foundation aim of the institution. Development of the profit-oriented projects on public land either through subsidiary firms or through public-private partnerships is appropriation of public land, which leads to a transfer of the urban rent. Planning competences of TOKİ have been empowered, and TOKİ has become the largest developer in the country and most influential actor of the neoliberal policies. Consequently more direct appropriation of the urban rent have been enabled. Activities such as increasing development rights and selling public land to private sector for property investments have become common practice, resulting in the redistribution of the urban rent. In turn, the new redistribution patterns shape the new power dynamics prevaling in the formation of urban policies.

Urban transformation projects involving compulsory purchase of land, project generation, plan approval have further enhanced the authority of TOKI enormously. Local governments have the power to delineate areas and prepare plans for urban transformation projects due to the Local Administration Reforms of 2004 and 2005. However, these reforms indicate that development plans for these projects are to be approved in three months by the local governments, otherwise TOKİ has the authority to enforce the plan. By this way, local governments become dysfunctional and local development decisions and controls are bypassed. Each legal and institutional change constitutes a step towards strengthening the power of TOKİ while weakening that of local governments.

Urban transformation projects carried out by TOKİ, which aim to transform gecekondu areas into authorised housing is an indication of the zero gecekondu policy (7) of the 2000s (Erman, 2012; Kuyucu and Ünsal, 2010). The urban transformation projects shift the focus from the city center to the periphery of cities. As a result gecekondus once again become commodities to be exchanged in the market. Power dynamics that play significant roles in the effectiveness of urban policies have been shaped by the redistribution of the urban rent. At the last instance of proliferating neoliberal policies, those actors that share the urban rent have increased in size in addition to their more diversified profiles.

The scope and applicability of urban transformation projects are broadened with the enactment of the Law no. 5366. The law initially proposed the reconstruction and renewal of the historical and cultural conservation areas in the inner city. Municipalities and special provincial administrations are the authorised institutions to implement urban transformation projects in the deteriorated parts of conservation areas. The restrictions and regulations on the development of special urban areas are also removed. As a result not only public land in the periphery of cities, but also historical and cultural conservation areas in inner cities have been transformed in the quest to transfer the urban rent.

The enactment of Law no. 6306 on urban transformation in 2012 along with the establishment Ministry of Environment and Urbanism in 2011 widen the scope of urban transformation projects while reinforcing the authority of central government. The institutional framework for the application of this is provided by the Ministry of Environment and Urbanism. The 
intention of this law is to specify the principles, methods and processes in connection with the rehabilitation, demoliton and reconstruction at disaster prone areas. In fact, this particular legal framework covers almost all development areas in cities. The Law no. 6306, even, may give the authority to conduct compulsory purchase for the properties of those owners who do not consent the implementation of the transformation project. The continuation of urban transformation projects under the control of central goverment constitutes the domain of current urban policy.

\section{CONCLUSION}

This paper assesses the relations between evolving legal and institutional frameworks of urban policies and prevailing power dynamics with regard to different phases of neoliberal urban policies in Turkey. The roll-back phase of the 1980s and 1990s involved deregulation in response to global changes, which led to the further need for reforms. The roll-out phase of the 2000s incorporated legal and institutional restructuring that initially showed indications of governance forms. An inquiry into the evolution of urban policy in Turkey indicates feeble attempts toward the devolution of power. Governance attempts have often been frail mainly owing to inconsistent policies that redistributed policy making competences to central governments institutions. Neoliberal urban policies have had profound impact on the power dynamics of different actors, ranging from the central government to various components of the civil society. The EU accession process stepped up the transition to the decentralisation of power, leading to a form of governance. In recent years, however, centralisation of power embodied in a central government institution, i.e. TOKİ, reemerged and revealed in proliferating urban transformation policy.

Managing the urban rent became a major instrument of neoliberal urban policies for attaining capital accumulation and for the transfer of power since the 1980s. Neoliberal urban policies consider urban land as a tool for economic development while distributing the urban rent not only to the entrepreneurial actors, but also to gecekondu owners, irrelevant of the inequality embedded in the distribution mechanisms and processes. Urban transformation projects of the 2000s in the inner historical and cultural conservation areas cause a serious loss in authenticity while the demolitions of the gecekondu areas in the periphery threaten the property and sheltering rights. The neglect of socio-economic dimension in these projects and lack of participation result in disaccord of the civil society.

The guidance of central government power has always constituted a very significant characteristic of urban policy in Turkey. Legal and institutional frameworks have been adopted to provide operational tools for the prevailing interventionist attitude. All in all cities are often considered to be the domain for the redistribution of urban rent within the context of intertwined power dynamics. Different actors have played varying roles depending on their power whereas sharing the urban rent has been a common focus through different phases of neoliberalism.

The tendencies for specifiying priviledges to the central government have accelerated under the effects of neoliberal policies. The central governments' entrepreneurial interferences in urban development by using TOKI as an institution with the introduction of corresponding changes in the legal and institutional frameworks constituted the basis of 
urban transformation policy. Local governments as well as private sector initiatives have also shown an increasingly neoliberal altitude in urban development. Centrality of power in urban policy making particularly in the case of urban transformation projects ascertained the reconcentration of power. The need for creative urban intervention policies and planning instruments for complex urban development processes are clear. A new understanding of complex urban dynamics would be developed along with further research on current dynamics of neoliberal agenda.

\section{BIBLIOGRAPHY}

BALABAN, O. (2012) The Negative Effects of Construction Boom on Urban Planning and Environment in Turkey: Unraveling the Role of the Public Sector, Habitat International (36) 26-35.

BREDA-VÁZQUEZ, I., CONCEIÇÃO, P., FERNANDES, R. (2009) Partnership Diversity and Governance Culture: Evidence from Urban Regeneration Policies in Portugal, Urban Studies 46(10) 221338.

BRENNER, N., THEODORE, N. (2002) Cities and Geographies of 'Actually Existing Neoliberalism', Antipode 34(3) 348-79.

BRENNER, N., THEODORE, N., PECK, J. (2009) Variegated Neoliberalization: Geographies, Modalities, Pathways, Global Networks 10(2) 1-41.

BUĞRA, A. (1998) The Immoral Economy of Housing in Turkey, International Journal of Urban and Regional Research (22) 303-17.

EC, European Commission (2012) Turkey 2012 Progress Report [http://www. abgs.gov.tr/index.php?p=123\&l=2] Access Date (21.02.2013).

ERAYDIN, A. (2012) Contradictions in the Neoliberal Policy Instruments: What is the Stance of the State?, Contradictions of Neoliberal Planning, Cities, Policies and Politics, eds. T. Taşan-Kok, G. Baeten, Springer, Dordrecht; 61-77.

ERDER, S. (1996) İstanbul'a Bir Kent Kondu: Umraniye, İletişim Yayınları, İstanbul.

ERMAN, T. (2012) Urbanization, Urbanism and Urbanity, The Routledge Handbook of Modern Turkey, eds. M. Heper, S. Sayarı, Routledge, London; 293-302.

ERSOY, M. (1992) Relations between Central and Local Governments in Turkey: A Historical Perspective, Public Administration and Development (12) 325-41.

FAINSTEIN, S. (1991) Promoting Economic Development: Urban Planning in the United States and Great Britain, Journal of the American Planning Association 57(1) 22-33.

FINKEL, A. (1990) Municipal Politics and the State in Contemporary Turkey, Turkish State, Turkish Society, eds. A. Finkel, N. Sirman, Routledge, London; 185-218.

HARVEY, D. (2005) A Brief History of Neoliberalism, Oxford University Press, Oxford.

HEALEY, P. (2007) Urban Complexity and Spatial Strategies: Towards a Relational Planning for Our Times, Routledge, London. 
HEPER, M. (1986) Local Government in Turkey: An Overview with Special Reference to the Municipalities, Dilemmas of Decentralization: Municipal Government in Turkey, ed. M. Heper, Friedrich-Ebert Stiftung, Bonn.

IŞIK, O., PINARCIOĞLU, M.M. (2001) Nöbetleşe Yoksulluk, İletişim Yayınları, İstanbul.

JESSOP, B. (2002) Liberalism, Neoliberalism, and Urban Governance: A State-theoretical Perspective, Antipode 34(3) 452-72.

KALAYCIOĞLU, E. (1989) Division of Responsibility, Local Government in Turkey: Governing Greater İstanbul, ed. M. Heper, Routledge, London.

KARAMAN, O. (2013) Urban Neoliberalism with Islamic Characteristics, Urban Studies (50:16) 3412-27.

KESKİNOK, Ç. (2006) Kentleşme Siyasaları, Kaynak Yayınları, İstanbul.

KEYDER, Ç., ÖNCÜ, A. (1993) İstanbul and the Concept of World Cities, Friedrich Ebert Foundation, İstanbul.

KEYDER, Ç. AND ÖNCÜ, A. (1994) Globalisation of a Third World Metropolis: İstanbul in the 1980s, Review 17(3) 383-421.

KUYUCU, T., ÜNSAL, O. (2010) 'Urban Transformation' as State-led Property Transfer: An Analysis of Two Cases of Urban Renewal in İstanbul, Urban Studies 47(7) 1479-99.

LAGENDIJK, A., KAYASÜ, S., YAŞAR, S. (2009) The Role of Regional Development Agencies in Turkey from Implementing EU Directives to Supporting Regional Business Communities?, European Urban and Regional Studies 16(4) 383-96.

LE GALÈS, P. (2002) European Cities: Social Conflicts and Governance, Oxford University Press, Oxford.

LOVERING, J., EVREN, Y. (2011) Urban Development and Planning in İstanbul, International Planning Studies 16(1) 1-4.

LOVERING, J., TÜRKMEN, H. (2011) Bulldozer Neo-liberalism in İstanbul: The State-led Construction of Property Markets, and the Displacement of the Urban Poor, International Planning Studies (16:1) 73-96.

MCGUIRK P. (2000) Power and Policy Networks in Urban Governance: Local Government and Property-led Regeneration in Dublin, Urban Studies 37(4) 651-72.

MCGUIRK, P. (2005) Neoliberalist Planning? Re-thinking and Re-casting Sydney's Metropolitan Planning, Geographical Research 43(1) 59-71.

MINISTRY OF INTERIOR (2011) Local Authorities in Turkey, General Directorate of Local Authorities, Ankara.

MOULAERT, F., SCOTT, A. (1997) Globalisation, Economic Restructuring and Urban Society, Cities, Enterprises and Society on the Eve of the 21st Century, eds. F. Moulaert, A. Scott, Pinter, London.

NICHOLLS, W. J. (2005) Power and Governance: Metropolitan Governance in France, Urban Studies 42(4) 783-800. 
OECD (2008) İstanbul, Turkey, OECD Territorial Report [http://www.oecdilibrary.org/urban-rural-and-regional-development/oecd-territorialreviews_19900759] Access Date (21.02.2013).

PARLAK, B., SOBACI, M.Z., ÖKMEN, M. (2008) The Evaluation of Restructured Local Governments in Turkey Within the Context of the European Charter on Local Self-Government, Ankara Law Review 5(1) 23-52.

PECK, J. (2010) Constructions of Neoliberal Reason, Oxford University Press, Oxford.

PECK, J., TICKELL, A. (2002) Neoliberalizing Space, Antipode 34(3) 380-404.

PECK, J., THEODORE, N., BRENNER, N. (2009) Neoliberal Urbanism: Models, Moments, Mutations, SAIS Review XXIX(1) 49-66.

SAGER, T. (2011) Neo-liberal Urban Planning Policies: A Literature Survey 1990-2010, Progress in Planning (76) 147-99.

SYWNGEDOUW E., MOULAERT, F., RODRIGUEZ, A. (2002) Neoliberal Urbanization in Europe: Large-Scale Urban Development Projects and the New Urban Policy, Antipode 34(3) 542-77.

ŞENGÜL, H.T. (2009 [2001]) Kentsel Çelişki ve Siyaset: Kapitalist Kentleşme Süreçlerinin Eleştirisi (Second edition), İmge, Ankara.

ŞENYAPILI, T. (2004) Charting the 'Voyage' of Squatter Housing in Urban Spatial 'Quadruped', European Journal of Turkish Studies (Thematic Issue No1 - Gecekondu).

TSI, Turkish Standart Institute (2014) Population Statistics and Projections [http://www.turkstat.gov.tr/VeriBilgi.do?alt_id=39] Access Date (21.02.2013).

TÜRKÜN, A. (2011) Urban Regeneration and Hegemonic Power Relationships, International Planning Studies 16(1) 61-72.

Alındı: 01.06.2014; Son Metin: 20.11.2014

Anahtar Sözcükler: Neoliberalizm; yasal ve kurumsal yapı; kentsel politika.

\section{TÜRKIYYE'DE NEOLİBERAL KENTSEL POLİTIKKALARIN YASAL VE KURUMSAL YAPISININ EVRIMII}

Bu çalışmada Türkiye'de neoliberal kentsel politikaların yasal ve kurumsal yapısının son otuz yılda geçirdiği değişimler incelenmektedir. İncelemede merkezi ve yerel yönetimler arasındaki yetki ve güç kaymalarına vurgu yapılarak, farklı toplumsal aktörlerin karar verme süreçlerine katılımına dikkat çekilmektedir. Türkiye'de farklı aşamalarla biçimlenen neoliberal kentsel politikalar, çekilme (roll-back) ve açılma (roll-out) aşamaları kapsamında tartışılmaktadır (Peck ve Tickell, 2002). Birinci aşama, 1980'li yıllarda başlayan çekilme aşaması, devlet müdahalelerinin piyasalardan geri çekilmesini ifade etmektedir. Denetimlerin azaltılması ve serbestleştirme süreçleri de bu aşamada gündeme gelmektedir. İkinci aşamada, bunu izleyen açılma aşamasının yer alması öngörülmektedir. Bu aşama, farklı toplumsal aktörleri karar verme mekanizmalarına yaymayı hedefleyen yasal ve kurumsal yeniden yapılanmaları ve yönetişim süreçlerini içermektedir. Türkiye'de özellikle 2000'li yılların başında Avrupa Birliği mevzuatına uyum sağlama çalışmalarıyla hız kazanan yasal 
ve kurumsal yeniden yapılanma girişimleri, kentsel politikalar bağlamında da değişimlere uğramıştır. Bu makalede Türkiye'de neoliberal kentsel politikalar kapsamında birinci aşamaya ilişkin uygulamaların görece etkili olduğu ancak ikinci aşamanın uygulamada karşılık bulamadığ1 tartışılmaktadır. Neoliberal politikalar, öncelikle rekabeti destekleyen serbest piyasa mekanizmaları kapsamında devletin geri çekilme aşamasında uygulanırken, karar verme mekanizmalarını açarak toplumsal aktörlere yayma aşaması gerçekleşememiştir. Çalışmada farklı ülkelerde neoliberalizmin açılma aşamalarında yönetişim süreçlerinin merkezi ve yerel yönetimlerle diğer toplumsal aktörler arasındaki ilişkileri etkileme biçimleri de ele alınmaktadır. Bu anlamda farklılaşmış ve bağlam-bağımlı olan süreçlerin merkezi yönetimlerle ilişkilerindeki farklılıklara dikkat çekilmektedir. Türkiye'de de merkezi ve yerel yönetimler arasındaki yetki ve güç dağılımındaki değiş̧imler kentsel politikaları ve kentte yaratılan değerin yeniden dağıtımını etkilemeyi sürdürmektedir.

SERAP KAYASÜ, B.C.P., M.A., Ph.D.

Received her bachelor of city planning at METU, her Master's degree at the University of Waterloo in Canada, and her PhD degree at METU. She worked in the urban transformation projects as a planner. She is currently an Associate Professor in the Department of City and Regional Planning at METU. Her research interest areas include institutional aspects of city and regional planning, regional development institutions, women and the city, and urban transformation. She has carried out a number of research projects and published in these areas.

EMINE YETIŞKUL, B.C.P., M.C.P., Ph.D.

Received her bachelor of city planning and master of city planning at METU, the degree of doctor of engineering in 2006 in the Department of Civil Engineering at Kyoto University in Japan. She has conducted research in the Institute of Transportation Studies at UC, Berkeley, USA. She has also worked as a city planner in the Ministry of Public Works and Settlement. Currently employed as Associate Professor in the Department of City and Regional Planning at METU. She works on urban and transport economics and urban transformation. 